\title{
REGIONAL DIFFERENTIATION OF HIGHER EDUCATION SERVICES IN UKRAINE
}

\author{
'Kateryna SAMSONYUK, Tetiana STETSENKO, Olena PETRYK \\ Taras Shevchenko National University of Kyiv, Ukraine \\ 'katerina_samsonyuk@ukr.net
}

\begin{abstract}
The article characterizes regional distribution of higher education institutions and students in Ukraine and identifies factors that cause it. The most outstanding and influential international and domestic university rankings have been analyzed and alternative assessment were suggested. The authors have analyzed the results of sociological survey of students about higher education services.

Key words: higher reducation, higher education institution, regional differentiation, factors, quality of educational services, rating

UDC: 911.3
\end{abstract}

\section{РЕГІОНАЛЬНА ДИФЕРЕНЦІАЦІЯ ПОСЛУГ ВИЩОЇ ОСВІТИ В УКРАЇНІ}

\author{
'Катерина САМСОНЮК, Тетяна Стеценко, Олена ПЕТРИК \\ Київський начіональний університет імені Тараса Шевченка, Україна \\ 'katerina_samsonyuk@ukr.net
}

\begin{abstract}
Анотація: Охарактеризовано регіональний розподіл вищих навчальних закладів та студентів в Україні та визначено чинники, які його зумовлюють. Проаналізовано найбільш визначні та впливові міжнародні та вітчизняні університетські рейтинги, запропоновано альтернативні оцінки. Здійснено аналіз результатів соціологічного опитування студентів щодо послуг вищої освіти.

Ключові слова: вища освіта, вищий навчальний заклад, регіональна диференціація, чинники, якість освітніх послуг, рейтинг

УДК: 911.3

Вступ. Постановка проблеми. Вищій освіті належить особлива роль у соціальній сфері держави оскільки сьогодні в суспільстві знань першорядного значення набуває інтелектуальний капітал, що найефективніше формується в закладах вищої освіти та науково-дослідницьких інституціях. Особливий

(C) К. Самсонюк, Т. Стеценко, О. Петрик

статус вищої освіти пояснюється тим, що саме в 1ii закладах відбувається передача накопиченого в суспільстві наукового знання від покоління до покоління. Важливим $є$ i те, що заклади вищої освіти різного профілю приймають безпосередню участь у формуванні професійно-кваліфікаційних знань та навичок трудових ресурсів. Вищезазначене обумовлює актуальність написання даної статті.
\end{abstract}


Аналіз останніх досліджень і публікацій. Дослідженням вищої освіти в Україні займалися представники різних наук: філософи, історики, правознавці, педагоги, фахівці 3 державного управління, географи.В суспільній географії вища освіта, як складова сфери послуг, розглядалась в працях В. М. Юрківського, I. М. Дудника, Л. М. Нємець. Дослідженню територіальної організації закладів освіти в Україні присвячена дисертаційна робота Т. Ю. Мельниченко, закладів вищої освіти - дисертація К. О. Січкаренка. Аналіз регіональної специфіки вищої освіти на рівні областей в Україні був здійснений в дисертаційних дослідженнях П. Вірченка, Н. Горожанкіної, Н. Флінти, В. Панкратьєвої та інших вчених. Однак тема регіональної диференціації послуг вищої освіти в Україні, якості наданих освітніх послуг недостатньо чітко представлена в сучасних суспільно-географічних дослідженнях і потребує окремого вивчення.

Формування цілей, постановка завдання. Метою роботи є вивчення регіональної диференціації послуг вищої освіти в Україні. Мета пов'язана із виконанням таких завдань: виявлення регіональних відмінностей розміщення закладів вищої освіти та кількості студентів в регіонах; оцінка регіональних відмін рівня надання послуг вищої освіти; виявлення та аналіз чинників, що зумовлюють регіональну диференціацію надання послуг вищої освіти; вивчення та узагальнення міжнародних рейтингів університетів; визначення відмінностей у вартості освітніх послуг в розрізі регіонів України та спеціальностей; аналіз результатів соціологічного опитування студентів 3 питань якості освіти.

Виклад основного матеріалу. Вища освіта - сукупність систематизованих знань, умінь i практичних навичок, способів мислення, професійних, світоглядних i громадянських якостей, морально-етичних цінностей, інших компетентностей, здобутих у вищому навчальному закладі (науковій установі) у відповідній галузі знань за певною кваліфікацією на рівнях вищої освіти, що за складністю є вищими, ніж рівень повної загальної середньої освіти [2].

Структура вищої освіти України відповідає структурі освіти розвинених країн світу та включає у себе п’ять рівнів від початкового до наукового.

Мережа вищих навчальних закладів (ВН3) України I-IV рівнів акредитації налічує понад 820 закладів. Майже $60 \%$ складають ВН3 I-II рівнів акредитації та 40\% - ВНЗ III-IV рівнів акредитації. В системі вищої освіти України функціонують 199 університетів, 64 академії, 89 інститути, 243 коледжів, 109 технікумів, 118 училищ та 1 консерваторія. Із 489 вищих навчальних закладів I-II рівнів акредитації 208 державної форми власності, 207 - комунальної та 74 - приватної.

Найвища концентрація ВНЗ у столиці (115), Донецькій, Харківській та Дніпропетровській областях. Найменша кількість ВН3 характерна для Волинської, Закарпатської, Кіровоградської, Рівненської та Миколаївської областей (17). Розподіл кількості студентів за областями подібний. По 100-150 тис. студентів навчаються у Донецькій, Львівській та Одеській областях, понад 150 тис. - у Дніпропетровській, Харківській областях та м. Київ. В цих трьох регіонах навчається понад 1500 студентів в розрахунку на 10 тис. жителів. Розподіл вищих навчальних закладів за регіонами та кількість студентів на 10 тис. населення представлено на рис. 1.

Порівнюючи чисельність студентів ВНЗ у 1990/91 навчальному році із сучасною, можна виявити такі особливості: кількість студентів у вищих навчальних закладах I-II рівня акредитації скоротилась більш ніж у два рази ( із 757 тис. до 345,2 тис. осіб); чисельність студентів у вищих навчальних закладах III-IV рівня акредитації зросла більше, ніж у два рази ( iз 881,3 тис. осіб до 1824,9 тис. осіб).

Чисельність студентів у ВНЗ I-II рівнів акредитації на кожні 10 тис. населення України складає 72 особи, у ВНЗ III-IV рівнів акредитації 380 осіб.

Підготовка фахівців 3 вищою освітою здійснюється за 70 напрямами, які включають понад 500 спеціальностей. У 2013 році ВН3 I-II рівнів акредитації було випущено 91,2 тис. осіб, III-IV рівнів акредитації-485,1 тис. осіб.

У 2012/2013 навчальному році у ВНЗ І-ІІ рівнів акредитації працювало 36,3 тис. педагогічних та науково-педагогічних працівників, у ВНЗ III-IV рівнів акредитації-158,9 тис., в т.ч. 71,4 тис. кандидатів наук та майже 14,4 тис. докторів наук, 48 тис. доцентів та майже 12,7 тис. професорів.

Протягом 2010-2013 років в Україні було створено 13 регіональних університетських центрів на базі 33 вищих навчальних закладів. 14 вищим навчальним закладам України надано статус дослідницького, серед ВНЗ III-IV рівнів акредитації 118 закладів мають статус національного.

За угодами міжурядового та міжвідомчого характеру щорічно близько 300 осіб направляються 3 України за кордон для здобуття освіти у ВНЗ. У рамках прямих угод між українськими та закордонними ВНЗ щорічно за кордон на навчання та стажування їде близько 4000 осіб. Державна підтримка i фінансування навчання та стажування за кордоном у вищих навчальних закладах США, Великобританії, Франції, Німеччини, Японії та інших економічно розвинених країн надається студентам, аспірантам i фахівцям таких напрямків, як IT-технології, біонанотехнологіі, інформаційно-комунікаційні технології, нанофізика та наноелектроніка, електротехніка, нові нетрадиційні джерела енергії, раціональне природокористування, розробка корисних копалин, металургія, машинобудування, авіаційна та ракетно-космічна техніка, атомна енергетика, хімічна технологія та інженерія.

Порівняно 3 іншими країнами світу, Україна має значну кількість вищих навчальних закладів. За показником кількості ВН3, які припадають на 1 млн. жителів Україна займає одне 3 перших місць у світі $(7,3)$. Також високим цей показник є у Чехії, Франції та Болгарії. 


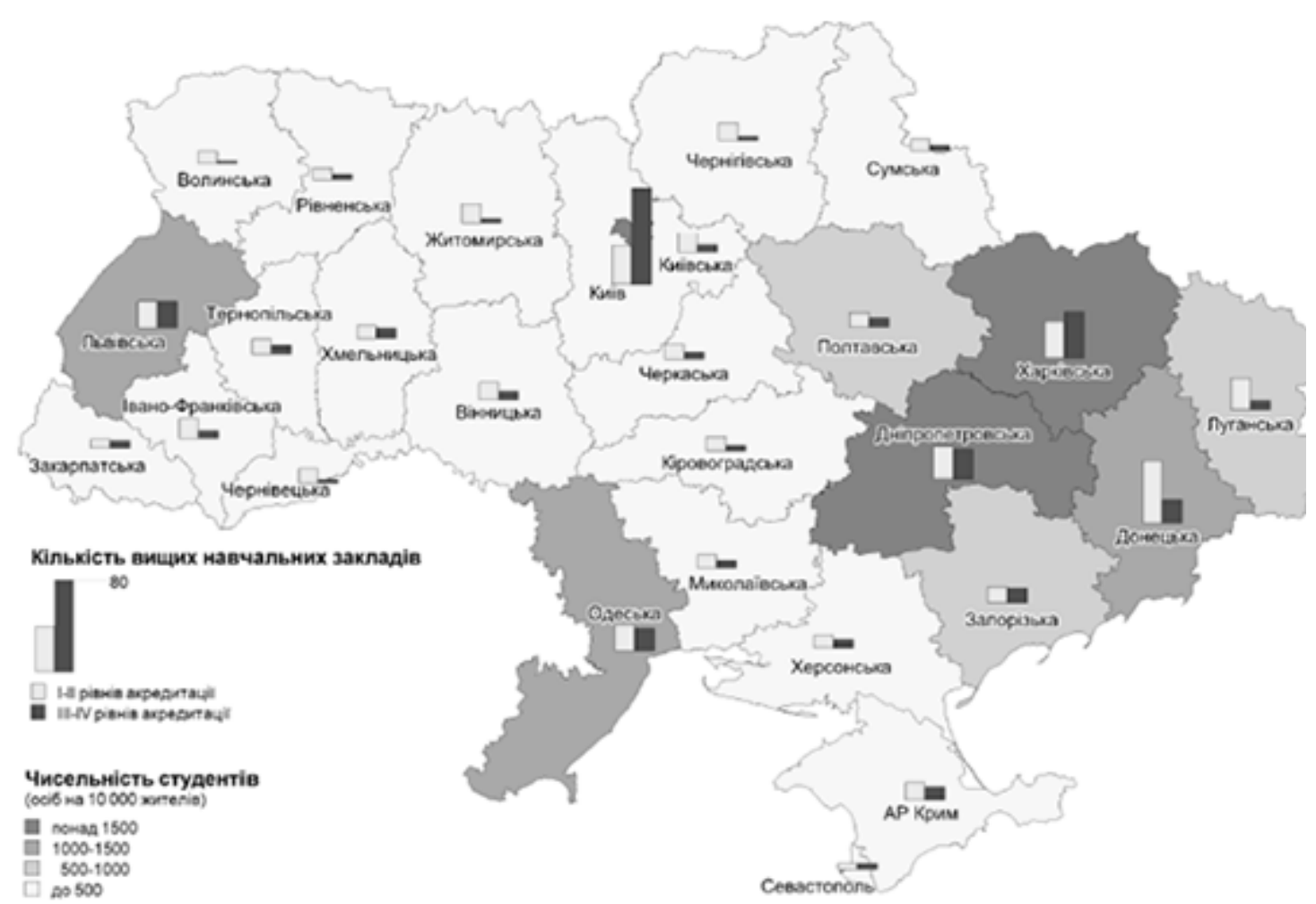

Рис. 1. Розподіл закладів вищої освіти та студентів за регіонами України у 2013 році

Регіональна диференціація надання освітніх послуг в Україні склалася під впливом великої кількості факторів та умов, що взаємопов'язані між собою. Важливим є показник соціально-економічного розвитку регіону. Найбільша кількість ВНЗ розміщена в Києві, який лідирує практично за всіма соціальноекономічними показниками. Суттєвим для освітнього закладу є географічне положення. Розміщення ВНЗ у столиці чи у великих містах дає ряд конкурентних переваг.

3 метою більш глибокого аналізу факторів, що впливають на кількість студентів у регіоні було здійснено кореляційний аналіз. Для дослідження було обрано наступні показники: кількість студентів в регіоні, кількість ВНЗ, ВРП на 1 особу, наявні доходи на душу населення, капітальні інвестиції, середньомісячна заробітна плата, рівень безробіття та чисельність постійного населення. Метою аналізу було встановити залежність кількості студентів у регіоні від соціально-економічних показників. Усі коефіцієнти кореляції знаходяться у межах $0,6<\mathrm{rxy}<0,9$, таким чином зв'язок між показниками достатній. Значення додатні, отже і зв'язок прямий. Усе $є$ доволі логічним: чим більше ВНЗ у регіоні (більша пропозиція місць для навчання), чим вищий ВРП, доходи, капітальні інвестиції та зарплата (економічний рівень), тим більша кількість студентів у регіоні. Дещо менший вплив становить чисельність населення. Це можна пояснити особливостями вікової структури у регіонах та мобільністю молодого населення. Виняток становить зв'язок кількості студентів із рівнем безробіття. Тут знак коефіцієнта $\epsilon$ від'ємним, тобто чим вищий рівень безробіття, тим менша кількість студентів у регіоні, що теж логічно, оскільки утримання студента потребує значних матеріальних затрат з боку сім'ї. Але значення $-0,4$ свідчить про наявність лише слабкого зв'язку у цьому відношенні.

Останнім часом все частіше для оцінки якості освітніх послуг використовується рейтинговий метод. Практика складання університетських рейтингів нараховує вже понад тридцять років (перший університетський рейтинг, надрукований в журналі USNews\&WorldReport, з'явився в США у 1983 році). Протягом останніх 15 років у різних країнах світу почали розроблятися $\mathrm{i}$ широко застосовуватися різноманітні підходи та методики до визначення рейтингів університетів. Така робота поступово вийшла за межі національних рамок і набула регіонального та міжнародного характеру.

Визначення певного рейтингу, тобто інтегрального показника якості діяльності вищих навчальних закладів, у першу чергу обумовлене необхідністю взаємного визнання навчальних програм і університетів у Болонському просторі. Також це обумовлено, з одного боку, потребами роботодавців на ринку праці 3 метою орієнтації на випускників тих чиінших рейтингових університетів, а 3 іншого - потребами абітурієнтів та їх батьків під час вибору закладу вищої освіти для майбутнього навчання. Постійне визначення й оприлюднення рейтингів університетів породжує, окрім іншого, й здорову конкуренцію між ними, що суттєво сприяє підвищенню якості їх роботи.

Очевидно, що високе місце в академічному рейтингу $\epsilon$ дуже зручним інструментом для маркетингу і просування університетів та навчальних програм. 
Роль світових координаторів із напрацювання та застосування методологій і підходів визначення рейтингів ВНЗ взяли на себе Інститут стратегії вищої освіти (Institute for Higher Education Policy, Вашингтон, США) та Європейський центр ЮНЕСКО у сфері вищої освіти (ЮНЕСКО - СЕПЕС, Бухарест, Румунія). Першим із світових університетських рейтингів став складений у червні 2003 року Інститутом вищої освіти Шанхайського університету (Китай) “Рейтинг університетів світового класу" ("Ranking of World Class Universities"), або Шанхайський рейтинг. Жодного українського вищого навчального закладу серед п'ятисот найкращих університетів світу в ньому немає.

Іншим визнаним рейтингом світових університетів є рейтинг Таймс, або THE - QS World University Rankings, який вперше був опублікований у 2004 р. і постійно складався із 200 університетів. Починаючи 2010 р. рейтинг Таймс як спільний проект THE та QS перестав існувати, а на йогоосновівиникли два нові, потенційновпливові рейтинги.

За результатами рейтингу QS World University Rankings 2014/15 року два українські університети увійшли до Топ-500: Київський національний університет імені Тараса Шевченка (421-430 позиція) та Харківський національний університет імені В. Н. Каразіна (481-490). Також до рейтингу увійшли Національний технічний університет України «Київський Політехнічний Інститут» (551600), Сумський державний університет (651-700), Донецький національний університет (701+) та Національний технічний університет «Харківський Політехнічний Інститут» (701+). Варто зазначити, що СумДУ отримав особливу нагороду - 3 зірки QS (iз 6). Зірки присвоюються в результаті проведення спеціальної перевірки, яка враховує додаткові параметри, які не входять у рейтинг.

Від часу заснування рейтингу Times Higher Education World University Rankings жоден український університет не потрапив до списку Топ-400. Згідно даних 2014 року лідеромв ньому $є$ Гарвардський університет.

Ще одним рейтингом світових університетів $€$ рейтинг Вебометрикс, який розраховується спеціальною лабораторією Іспанської національної дослідницької ради з 2004 року. На відміну від попередніх, він має дещо специфічний характер, адже базується на ступені присутності того чи іншого навчального закладу в глобальній мережі Інтернет. Згідно останнього Ranking Web of World Universities жоден український університет не входить до Топ-500. Найвищу сходинку посідає Київський національний університет імені Тараса Шевченка(885).

Останнім часом інтенсивно розробляється європейський рейтинг світових університетів U-Multirank, який запущено в пілотному режимі. Його появі передувала розробка системи класифікації вищих навчальних закладів, U-map, що даєможливість зіставляти справді порівнювальні університети. Відповідно до цієї класифікації, кожен тип закладів матиме свій рейтинг і упорядники не будуть, образно кажучи, порівнювати «зелене 3 холодним». Цей рейтинг оцінюватиме університетську діяльність за п'ятьма основними напрямами: викладання i навчання; дослідницька активність; передавання знань; інтернаціоналізація; регіональна включеність. Базові методологічні принципи цього рейтингу передбачають, що його результати не будуть підсумовуватись у загальний бал. За бажанням можна порівняти обраний університет 3 іншим за рядом критеріїв

Серед українських ВНЗ для порівняння представлені, а відповідно і певним чином оцінені, Київський національний економічний університет імені Вадима Гетьмана, Київський національний університет імені Тараса Шевченка, Національний технічний університет України «Київський Політехнічний Інститут» та Національний університет «Києво-Могилянська Академія».

Таким чином, окремі українські ВНЗ присутні у деяких міжнародних рейтингах університетів та щороку покращують свої позиції. Насамперед, це стосується Київського національного університету імені Тараса Шевченка та Національного технічного університету України «Київський Політехнічний Інститут». Проте, їхні позиції порівняно низькі, а в деяких рейтингах українські ВНЗ взагалі відсутні, що може бути свідченням недостатньо високої якості вищої освіти в Україні та її визнання в світі.

Серед українських організацій, які мають власні рейтинги ВНЗ в Україні, ми проаналізували рейтинги Міністерства освіти і науки та рейтинг «Компас», який був ініційований компанією «Систем Кепітал Менеджмент» у рамках програми «Сучасна освіта».

Для оцінки регіональних відмінностей рівня надання послуг вищої освіти аналізуються процентні співвідношення таких показників: частка бюджету, що виділяється на освіту в регіоні; інвестиції в освіту в регіоні; кількість кандидатів і докторів наук за регіонами; кількість та технічне оснащення ВН3; кількість науково-дослідницьких інститутів; кількість переможців студентських наукових конкурсів, учасників конференцій молодих учених.

Так у рейтингу «Компас» було представлено 52 ВНЗ Києва, 44 ВНЗ Західного регіону, 28 ВН3 Центрального регіону (без Києва), 65 ВНЗ Південного регіону та 50 ВНЗ Східного регіону. Рейтинг містить комплексну оцінку, оцінку за напрямками підготовки та за регіонами. У Києві наявні найкращі можливості для отримання якісної освіти. Перше місце серед київських ВНЗ має Національний технічний університет України «Київський політехнічний інститут». Основним освітнім центром Західного регіону є Львів: саме там розташовані два найсильніші ВН3 регіону - Національний університет «Львівська політехніка» (перше місце у регіональному рейтингу і четверте - в загальнонаціональному) і Львівський національний університет імені Івана Франка (друге місце у регіональному рейтингу i сьоме - в загальнонаціональному). ВНЗ Центрального регіону слабо витримують конкуренцію на загальнонаціональному рівні. Найкращу оцінку серед ВНЗ регіону отримав Вінницький національний технічний університет (перше місце в регіоні, 
восьме в Україні).У Південному регіоні існує кілька вагомих освітніх центрів - Дніпропетровськ, Одеса, Запоріжжя. Хоча жоден із університетів Південного регіону не потрапив до п'ятірки найкращих на загальнонаціональному рівні, проте в цьому регіоні є ВНЗ, які забезпечують високий рівень підготовки, зокрема 3 інженерно-технічних, юридичних й архітектурно-будівельних спеціальностей. Загалом, за критеріями рейтингу, найкращими вищими навчальними закладами Південного регіону були названіДніпропетровськийнаціональнийуніверситет імені Олеся Гончара (перше місце в регіоні, сьоме в країні)таНаціональнийгірничийуніверситет України (перше місце в регіоні, сьоме в країні). Східний регіон пропонує непогані освітні можливості із основними освітніми центрами у Харкові і Донецьку. Серед ВНЗ Східного регіону перше місце отримав Донецький національний технічний університет, який на загальнонаціональному рівні має 4-те місце. Друге місце мають Національний технічний університет «Харківський політехнічний інститут» та Юридична академія України імені Ярослава Мудрого [1].

У рейтингу МОН здійснено ранжування ВНЗ IIIIV рівнів акредитації за результатами їх діяльності та потенціалом 2011/2012 навчального та 2012 календарного років.До рейтингу 2013 року включено 304 суб'єкти ранжування. Результати рейтингу представлено за группами вищих навчальних закладів (класичні, технічні, аграрні університети та ін.). Серед класичних університетів ключові місця посідають КНУ ім. Т.Шевченка, ХНУ ім. В.Каразіна, СумДУ, ОНУ ім. І.Мечникова, НУ «Острозька академія».

Певним свідченням якості навчання в університеті, на нашу думку, може бути участь студентів у різноманітних міжнародних та всеукраїнських грантових програмах i конкурсах. Нами було проаналізовано Наказ МОН «Про підсумки Всеукраїнського конкурсу студентських наукових робіт з природничих, технічних та гуманітарних наук у 2013/2014 навчальному році». Призові місця зайняли роботи із понад 200 різних навчальних закладів. За підсумками конкурсу, найбільша кількість переможців навчається у місті Харків (понад 300 осіб). Це ще раз підтверджує статус Харкова як одного iз потужних освітніх центрів України. Друге місце за кількістю переможців Конкурсу займає місто Київ, проте, з суттєвим відривом (понад 200). У Донецькій області, яка є третьою, навчається 170 переможців. Більш як по 100 переможних робіт було представлено iз Дніпропетровської, Львівської та Полтавської областей. У кожному з цих регіонів вклад у рейтинг зробили 5 і більше навчальних закладів. Цікавою $є$ ситуація у Сумській області, яка здобула 87 перемог, проте, 74 належать лише одному університету Сумському державному університету. Найменша кількість переможців навчається у Закарпатській області - всього три особи.

Проаналізовано список переможців Сьомого конкурсу Стипендіальної програми «Завтра.иа» (2012-2013 навчальний рік). Серед 320 переможців є представники 65 різних навчальних закладів України.

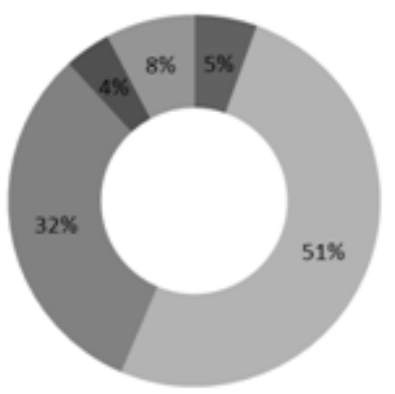

= O6ое'язково працюеатиму за cпеціальністо

" Маю намір, але не знаю, чи знайду відповідну poбory

- Hе планую працовати за спеціальністо

- я уже працюю за спеціальністо

Рис. 2. Результати відповідей студентів географічного факультету КНУ ім. Тараса Шевченка на питання «Чи плануєте Ви працювати за спеціальністю?»

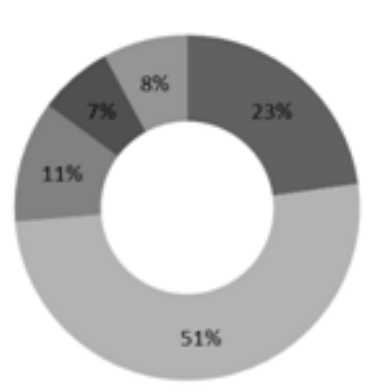

$$
\begin{aligned}
& \text { - O6ов'язкоео } \\
& \text { прачюезтиму за } \\
& \text { спеціальніспо } \\
& \text { = Маso namip, ane ve swan. } \\
& \text { чи знайду відповідну } \\
& \text { pocory } \\
& \text { = Не планую прачовати } 3 \\
& \text { cneujaльніспо }
\end{aligned}
$$

\section{Рис. 3. Результати відповідей студентів КНУ ім. Тараса Шевченка $з$ різних факультетів на питання "Чи плануєте Ви працювати за спеціальністю?»}

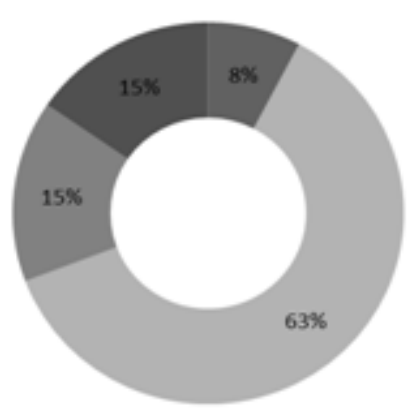

- O6oв'язмово працюеатиму 39 спеціальністо = Маю намір, але не знаю. чю знайду відаповіану po6ory

= He планую прачюеати за спеціальніспо

- Не визначиеся

\section{Рис. 4. Результати відповідей студентів геолого-географічного факультету}

\section{ХНУ ім. В.Н. Каразіна на питання «Чи плануєте Ви працювати за спеціальністю?»}

Лідером за кількістю переможців $є$ Київський національний університет імені Тараса Шевченка, де навчається понад $10 \%$ стипендіатів.

Вартість освітніх послуг в університетах України істотно відрізняється. Так, наприклад, різниця між середньою вартістю навчання зо ОКР «бакалавр» в ЧНУ та КНУ відрізняється у 2,4 рази, а за ОКР «магістр» - в 1,7 рази. При цьому, варто зазначити, що тривалість навчання зо ОКР «магістр» у ЧНУ та деяких інших університетах становить 1 рік, а у КНУ -2 роки. Таким чином, різниця у вартості навчання 


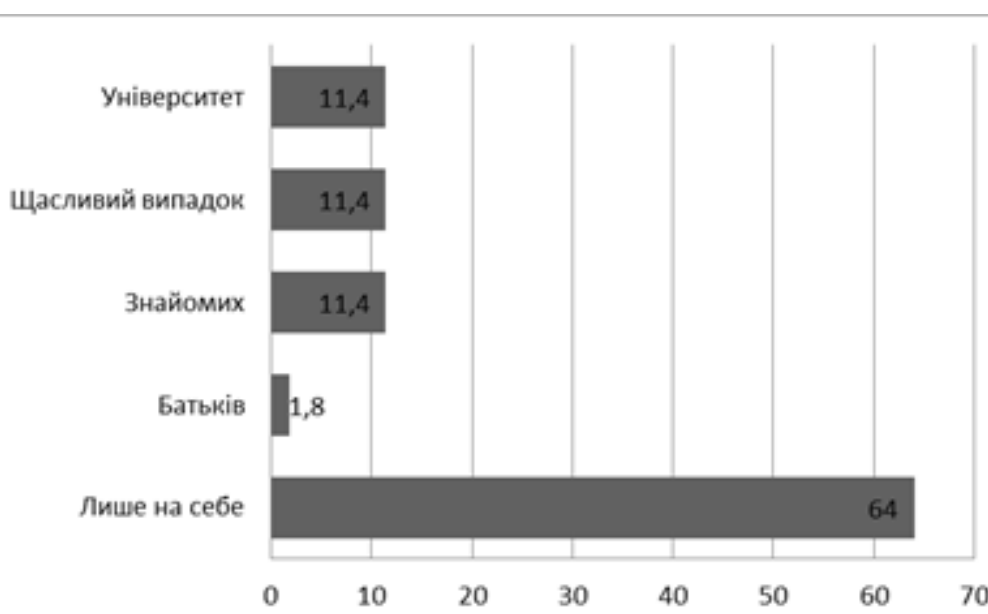

Рис. 5. Результати відповідей студентів різних факультетів КНУ ім. Тараса Шевченка на питання «На чию допомогу Ви розраховуєте при працевлаштуванні?»

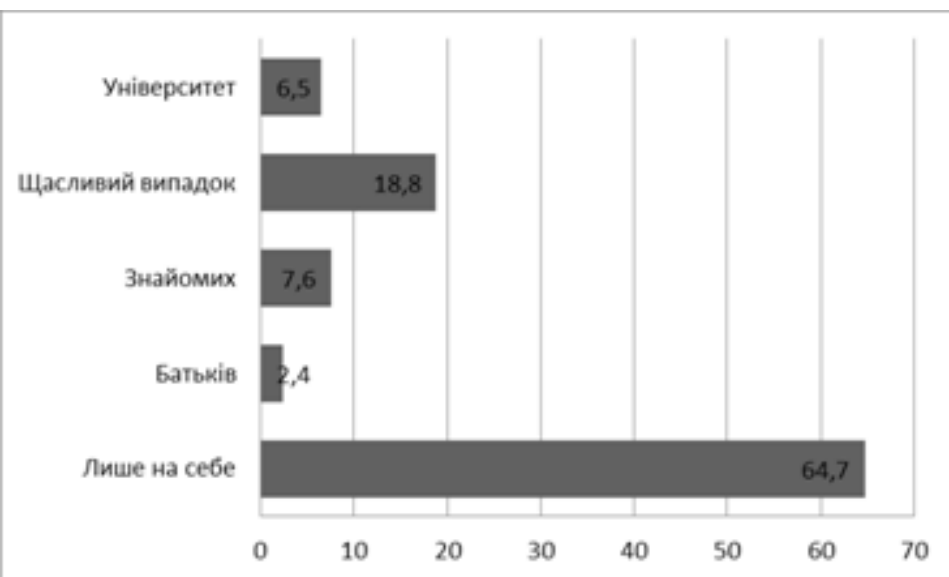

Рис. 6. Результати відповідей студентів географічного факультету КНУ ім. Тараса Шевченка на питання «На чию допомогу Ви розраховуєте при працевлаштуванні?»

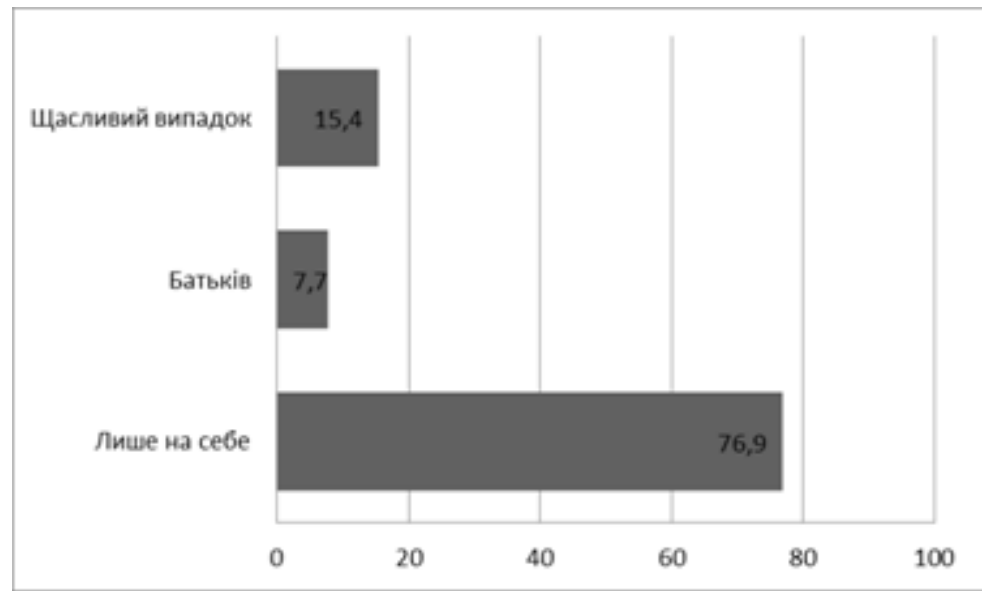

Рис. 7. Результати відповідей студентів геологогеографічного факультету ХНУ ім. В.Н. Каразіна на питання «На чию допомогу Ви розраховуєте при працевлаштуванні?» зростає.

Примітно, що 2 українські ВН3, які найчастіше потрапляють до міжнародних рейтингів, мають найвищу вартість освітніх послуг (ХНУ та КНУ). В усіх університетах вартість навчання у магістратурі вища за вартість навчання у бакалавраті. Лише у Дніпропетровському та Київському університетах ця різниця $є$ мінімальною, а за окремими спеціальностями іï взагалі немає.

Вартість освітніх послуг за окремим напрямками може свідчити про престижність на популярність окремих професій. Найнижча вартість на природничих та технічних факультетах. Найбільш популярними ж $є$ спеціальності «правознавство», «міжнародні відносини», «переклад» (англійська філологія). Цікавою $є$ ситуація, що склалася у Дніпропетровському національному університеті, де в число найдорожчих спеціальностей входить «хімія» (у Львівському ж університеті цей напрям $є$ одним із найдешевших). Таку ситуацію можна пояснити значним попитом на спеціалістів-хіміків.

Для оцінки якості надання послуг закладами вищої освіти було проведено соціологічне опитування. У ньому брали участь 347 респондентів: студенти геологогеографічного факультету Харківського національного університету імені В.Н.Каразіна, а також студенти різних факультетів Київського національного університету імені Тараса Шевченка. Анкетування проводилось двома шляхами: пряме опитування та опитування через мережу Інтернет. Виявилось, що останній спосіб дає доволі хороші результати в плані змісту відповідей: вони досить змістовні i добре обгрунтовані, оскільки людина має достатньо часу обдумати відповідь на запитання, крім того респонденти мали можливість залишити свої коментарі, а не лише дати відповідь на питання закритого типу.

Перейдемо до безпосередніх результатів.

1. Задоволеність вибраним вищим навчальним закладом. Більшість студентів задоволені власним вибором. Серед студентів м. Харкова - це 76,9 \%, студентів географічного факультету КНУ ім. Тараса Шевченка - 74,7 \%, а серед студентів інших факультетів - 78,9\%. Стосовно не задоволених, то серед географів - це $4,1 \%$, а серед інших студентів - 4,3\%. Решта дали відповідь «складно відповісти».

2. Задоволеністьвиборомспеціальності, за якою навчаєтесь. Більшість осіб, які навчаються на різних факультетах задоволені своєю спеціальністю, їх відсоток коливається 
від 61,5 до 69,3 .

3. Що було визначальним критерієм вибору ВНЗ та спеціальності?

Відповіді досить відрізняються у географів та студентів інших факультетів. Так для перших важливим критерієм стала престижність ВН3, а для частини це просто збіг обставин, для інших важливим був поклик серця.

4. Чи плануєте Ви працуювати за спеціальністю?

Найбільше осіб, які не збираються працювати за спеціальністю серед студентів географічного факультету КНУ ім. Тараса Шевченка (31,8 \%) (рис. 2 , рис. 3, рис. 4).

5. Як Ви оиінюєте Ваші шанси на працевлаштування за спеціальністю?

Оскільки нині спостерігається складна ситуація на ринку праці, всі респонденти реально розглядають можливість працевлаштування за спеціальністю i оцінюють свої шанси на середньому рівні. Найвище оцінюють свої шанси студенти факультету кібернетики, механіко-математичного та факультету інформаційних технологій. Це можна пояснити, перш за все, попитом на кваліфікованих програмістів та працівників IT сфери.

6. На чию допомогу Ви розраховуєте при працевлаштуванні? Дане питання можна поєднати iз наступним питанням, а саме: Як Ви оцінюєте якість отриманих Вами у ВНЗ знань?

Більшість опитаних відзначили, що якість знань достатньо висока і володіючи ними можна конкурувати на ринку праці. Відповідно, при працевлаштуванні більшість покладаються на себе. Існує у суспільстві думка, що без батьків у наш час влаштуватись на роботу дуже складно, однак серед респондентів тих, котрі розраховують на батьків, одиниці(рис. 5 , рис. 6 , рис. 7).

7. Як Ви вважаєте, чи допоможуть Вам отримані у ВНЗ знання при пращевлаштуванні?

Відповідь на це питання не $є$ однозначною, більшість опитаних або ж затрудняється відповісти, або ж, все таки, вважає, що здобуті знання їм допоможуть. Студентів, які відповіли негативно зовсім мало, серед географів - 11,8 \%, серед опитаних із інших факультетів - 18,4\%.

8. Чи здійснюєте Ви вдосконалення та поповнення своїх знань та навичок, необхідних для роботи й саморозвитку?
На сьогоднішній день проводиться значна кількість лекцій, курсів, тренінгів, які сприяють вдосконаленню тапоповненню знань. Серед опитаних більшість займається саморозвитком та навчанням поза межами ВНЗ.

9. Чи хотіли б Ви продовжити навчання за кордоном?

Відповіді на дане запитання значно відрізняються у студентів Харківського національного університету імені В. Н. Каразіна та Київського національного університету імені Тараса Шевченка. Серед харків’ян досить мало тих, які хотіли б продовжити навчання за кордоном. Найпопулярнішими країнами для продовження навчання $\epsilon$ країни $\mathrm{CC}$ : Німеччина, Польща, Італія, Чехія, Франція. Також багато бажаючих навчатись у США, Канаді. Були також зазначені такі країни, як ОАЕ, Китай, Корея, Японія студентами-філологами та студентами Інституту міжнародних відносин.

Висновки i перспективи подальших розробок. Робота $\epsilon$ спробою комплексного суспільно-географічного дослідження регіональної диференціації послуг вищої освіти в Україні. У ній застосовано набір методів дослідження, що дають змогу якомога більш повно вивчити та кількісно i якісно оцінити регіональні особливості розміщення закладів вищої освіти, регіональні відміни рівня наданняпослугвищоїосвіти; виявитиіпроаналізувати чинники, що зумовлюють такі відміни; визначити місце українських університетів у вітчизняних та міжнародних рейтингах; проаналізуватиміркування студентів 3 питань вищої освіти в Україні. У цьому полягає наукове та пізнавальне значення роботи для студентів, викладачів та менеджерів. Не менш важливим є і практичне значення роботи, оскільки отримані результати можна використовувати в навчальному процесі у середній та вищій школі, у профорієнтаційній діяльності.

Започаткована робота може бути основою для подальших наукових досліджень щодо моніторингу змін регіональної диференціації послуг вищої освіти в Україні; вивчення впливу прийнятого Закону України «Про вищу освіту» на дану проблему; дослідження просторової мобільності викладачів та студентів;вивчення зв'язків між диференціацією освітніх послуг, молодіжним безробіттям та трудовими міграціями.

\section{References:}

1. Analitičnij zvit rejtungu visish navčal’nih zakladiv Ukrä̈ni «Kompas - 2013» [Analytical report: rating of higher educational institutions of Ukraine "Compass-2013”]. Sistem Kepital Menedzment, 2013, 112 p. Access mode: http://www.scm.com.ua/m/documents/compas_2013_ukr.pdf(In Ukrainian).

2. Statističnij bûleten" "Osnovni pokazniki diầl'nosti viŝih navčal'nih zakladiv Ukraïni na počatok 2013/2014 navčal'nogo roku» [The statistical Bulletin «Main indicators of activity of higher educational establishments in Ukraine at the beginning of 2013/2014 academic year»]. The State Statistics Service of Ukraine; responsible for the issue V. Kalačova. Kyiv, 2014, 165 p.(In Ukrainian).

3. Zakon Ukraïni «Pro viŝu osvitu» [The law of Ukraine "On higher education"]. Official web portal of the Verkhovna Rada of Ukraine / Vidomosti Verhovnoï Radi (VVR) [Bulletin Of The Verkhovna Rada of Ukraine], 2012, № 37-38, 2004. Access mode: http://www.scm.com.ua/m/documents/compas_2013_ukr.pdf (In Ukrainian). 